\title{
Dijital Çağda Çocuk Yetiştirme ve Eğitim: Değişen Roller
}

\author{
GAMZE İNAN KAYA* \\ gamze.inan@istanbul.edu.tr \\ ORCID ID: 0000-0002-6658-506X
}

\begin{abstract}
Öz: Dijitalleşme günlük yaşamı her anlamda etkileyen bir süreç olarak çocuk ve gençlerin psikososyal gelişimi ve eğitimi açısından ebeveynler ve öğretmenlerin rolleri ve sorumluluklarında bir dönüşümü de beraberinde getirmektedir. Bu rol ve sorumluluklarm dayandı̆̆ anlayış genç kuşağın dijital öğrenme ve gelişme olanaklarından maksimum düzeyde faydalanmaların desteklerken; onların dijital risklerden korunmasını sağlamaktır. Çünkü gelinen noktada, dijital medya ve bu amaçla kullanilan teknolojik araçlar çocukların ve gençlerin yaşamalarının ayrılmaz bir parçası olmaya başlamıştır. Dijital okuryazarlğ̆ın önemine dikkat çekilerek, burada, dijitalleşme olgusunun çocuk ve gençlerin psikososyal gelişimi ve eğitimine yönelik dönüştürücü etkisi, yine dijital çağın getirisi olan öğrenme olanakları ve riskler açısından, ebeveynlerin ve öğretmenlerin değişen rollerine odaklanilarak tartışılmaktadır. Bu noktada ebeveyn ve öğretmenlerin bütüncül bir dijital okuryazarlık politikası kapsamında desteklenmesine yönelik ihtiyaç ifade edilmektedir.
\end{abstract}

Anahtar kelimeler: Dijitalleşme, Çocuk yetiştirme, Eğitim, Dijital olanaklar, Dijital riskler

\section{Giriş}

Dijitalleşme günlük yaşamı derinden etkilemekte ve dünyayı bir dönüşüme uğratmaktadır. Çağın kaçınılmaz bir olgusu olarak hayatın her alanında yaygın bir etkiye sahip olmaya başlayan bu süreçte artık gerçek kimliklerin yanında, 'dijital kimlikler' ve 'dijital ayak izinden' söz edilmektedir. ${ }^{1}$ Günlük yaşamda gözlenen bu değişimlerin insanlığın ilerlemesine ve yaşamın kolaylaşmasına katkısına dikkat çeken açıklamaların yanı sıra, bazı görüşler dijitalleşmenin bir sonucu olarak özgürlüklerin ve seçimlerin kaybına vurgu yaptıkları çerçeveler ortaya koymuştur. ${ }^{2}$ Günümüzde gelinen noktada, her iki görüşün de öngörülerinin doğruluğunu somut örneklerle görebilmek mümkündür. Örneğin, dijital çağın getirisi olan

\footnotetext{
${ }^{*}$ Dr. Öğr. Üyesi, İstanbul Üniversitesi, Hasan Ali Yücel Eğitim Fakültesi.

${ }^{1}$ Mats Sjöberg vd., "Digital Me: Controlling and Making Sense of My Digital Footprint", International Workshop on Symbiotic Interaction, der., Luciano Gamberini vd., Cham: Springer, 2016, s.155-167.

${ }^{2}$ Lokman Tsui, "The Panopticon as the Antithesis of a Space of Freedom: Control and Regulation of the Internet in China", China Information, 17/2 (2003), s.65-82; S. Zuboff, "Big Other: Surveillance Capitalism and the Prospects of an Information Civilization”, Journal of Information Technology, 30/1 (2015), s.75-89.
} 
internetin, bilgiye ulaşmayı saniyeler ile ölçülen bir hıza indirgediği açı olmakla birlikte; diğer yandan internette olmayan bilginin yokmuş gibi değerlendirilebildiği bir gerçeklik ile karşı karşıya kalınabilmektedir. ${ }^{3}$ Buradan hareketle, dijital çağın olanak ve kısıtları bir arada barındırdığını söylemek mümkün görünmektedir. Bu durum eğitim ve çocuk yetiştirme alanlarında da gözlenmektedir. Nitekim, eğitimde dijital teknolojik olanakların kullanılması, çocukların ve gençlerin dijital okuryazarlıklarının artırılması çağın bir gereği olarak ifade edilmekte; ${ }^{4}$ diğer yandan bu dönüşümün sonucunda dijital araçların artan kullanımının çocuklar ve gençlerin sosyal duygusal, fiziksel gelişimini ketleme riski karşısında tedbirlerin alınmasına yönelik açı ihtiyaç ortaya konmaktadır. ${ }^{5}$ Bir başka ifade ile, dijitalleşme sonucu değişen dünyada çocuk yetiştirme ve çocuğun psikososyal gelişimi ve eğitimi dikkate alındığında, olumlu ve olumsuz yönler iç içe geçmiş olarak izlenmektedir.

Prensky ${ }^{6}$ dijitalleşen dünyanın, toplumu kuşaklar açısından ikiye ayırdığını iddia etmiş ve 'dijital yerli' ve 'dijital göçmen' tanımlarını ortaya koymuştur. Buna göre, dijital yerli bu çağa ve çağın dijital gerçekliğine doğan, internet ve dijital teknoloji ile büyüyen kuşakları ifade ederken, dijital çağ öncesi doğan ve yetişkin yaşlarında bu araçlar ile tanışan kuşaklar, dijital göçmenlerdir. Bu kavramlar beraberinde, dijital teknolojilere ulaşma ve bunlardan yararlanmak için gereken bilgi, beceri, yaşantı açısından gözlenebilen eşitsizliğe işaret eden 'dijital bölünme' olgusunun ${ }^{7}$ kuşaklar arasında izlenmesini getirmektedir. Bu kuşaklar arası bölünmeye göre Prensky, kuşakların düşünme biçimleri, dünyayı anlamlandırma ve kavrama açısından teknolojinin yarattığı farkı yaşadıklarını, bu durumun da özellikle çocuklar ile onların yetişmesinden sorumlu yetişkinler arasına denk düştüğünü iddia eder. Bir başka ifade ile, dijital çağda doğan çocukların henüz dünyanın dijitalleşmeyi her alanda yaşamadığı dönemlerde doğmuş ve yetişmiş yetişkinlere kıyasla dijital uyumlarının daha fazla olduğu, iki kuşağın dünyayı algılama ve açıklama biçimlerinin birbirinden teknolojinin etkisi nedeniyle oldukça farklı olduğu söylenebilir. Bu görüş temelde, dijital teknolojilerin erken dönemlerde kullanımıyla çocuk zihninin üzerinde dönüştürücü bir etkisi olduğu varsayımına dayanmaktadır. Ancak dijital araçlar ile doğumdan itibaren tanışan ve dijital dünya düzeninde yetişen zihinler ile bu düzene katılan kuşaklar arasında zihinsel ve düşünme kapasiteleri açısından kapatılması güç farklardan söz edilemeyebilir. ${ }^{8}$ Diğer yandan, bu çağın bir getirisi olarak tüm bireyler için 'dijital okuryazarlık' olgusundan bahsetmek mümkündür. Bu kavram, dijital teknolojileri kullanarak bilgiye ulaşma, anlamlandırma, değerlendirme ve üretme kapasitesi ile bunun için gereken

\footnotetext{
${ }^{3}$ Reinhard Wentz, "Visibility of Research: FUTON Bias", The Lancet, 360/9341 (2002), s.1256.

${ }^{4}$ David Buckingham, "Defining Digital Literacy-What Do Young People Need to Know about Digital Media?”, Nordic Journal of Digital Literacy, 4/10 (2015), s.21-34.

${ }^{5}$ J. George Madeleine vd., "Concurrent and Subsequent Associations Between Daily Digital Technology Use and High-Risk Adolescents' Mental Health Symptoms", Child Development, 89/1 (2018), s.78-88; Sonia Livingstone vd., "Maximizing Opportunities and Minimizing Risks for Children Online: The Role of Digital Skills in Emerging Strategies of Parental Mediation", Journal of Communication, 67/1 (2017), s.82-105.

${ }^{6}$ Marc Prensky, "Digital Natives, Digital Immigrants" On the Horizon, 9/5 (2001), s.1-6. (erişim 15.08.2020).

7 Jan Van Dijk, "Digital Divide Research, Achievements and Shortcomings", Poetics, 34/4-5 (2006), s.221235.

${ }^{8}$ Ellen Johanna Helsper ve Rebecca Eynon, “Digital Natives: Where is the Evidence?”, British Educational Research Journal, 36/3 (2010), s.503-520.
} 
bilişsel, sosyal, duygusal, fiziksel ve teknik becerilere sahip olma olarak tanımlanabilir. ${ }^{9}$ Dijital çağa doğan kuşaklar öncekilere kıyasla bu anlamda artmış öğrenme olanaklarına sahip olsalar da, daha yüksek bir dijital okuryazarlık, kuşak farkından ziyade, dijital araçlara ulaşabilme ve yaygın olarak kullanabilme, ${ }^{10}$ bu araçlar sayesinde edinilen bilgiyi amaca yönelik işe koşabilme ve bilgi üretimine katkı sağlayabilme olanaklarına sahip olma ${ }^{11}$ ile bağlantılıdır. Zira ileri yaşlardaki yetişkinlerin de kişiselleşmiş dijital araçlara ulaşma imkânları ve sosyal güdülenmeleri ölçüsünde dijital okuryazarlıklarının arttığ 1 gözlenmektedir. ${ }^{12} \mathrm{O}$ halde, kuşakların dijital medya ile tanışma zamanları arasında bir fark olabilmekle birlikte, dijital dünyaya uyum sağlama açısından dijital yerlilerin dijital göçmenlere kıyasla daha avantajlı olduğu söylenemeyebilir. Bununla birlikte, dijitalleşmenin kuşaklar arasında düşünme biçimlerinde farklar yarattığını karşıt bir pozisyondan savunan diğer görüş ise, dijitalleşmenin insanların düşünme kalitelerini düşürdügü ve daha sığ düşünmeye yönlendirdiği tezidir..$^{13}$ Bu görüş de, yine kuşakların düşünme biçimleri ve kapasiteleri açısından karşılaştırılmasına dayanmakta, temelde dijital medya kullanımının artışının etkisiyle insanların zihinsel kapasitelerini yeterince kullanamayarak kaybetmeye başladıkları varsayımını öne sürmektedir. Bu görüş, televizyon çağ ile birlikte öne sürülmüş ve dijital medyanın hayatın her alanında olmaya başlaması sonucu ortaya çıkan yoğun kullanımının getirebildiği risklerin etkisini vurgulamıştır. ${ }^{14}$ Yukarıda ifade edilen iki görüşün de ortak noktası, dijital medyanın insan zihni üzerinde kısa sürede ortaya çıkan ve dönüştürücü bir rolü olduğu yönündedir. Bu nedenle her iki görüş de, dijitalleşme öncesi ve sonrasında kuşaklar arasında bir değişimin kaçınılmazlığı konusunda hem fikirdir. Ancak, insan zihninde ve düşünme biçimlerinde dijital çağın etkisiyle olumlu ya da olumsuz kökten bir değişimin gerçekleştiğine dair henüz yeterince açık kanıt sunulabildiğini söylemek güçtür.

Dijitalleşmenin kuşaklar arasında ortaya çıkardığı iddia edilen farklar, yukarıdaki açıklamalara kıyasla daha ılımlı bir noktadan incelenebilir. Dijital olanaklara ulaşma, kullanma ve yararlanma açısından bireyler arası ya da kuşaklar arası gözlenebilen farklılıklar, çocuk ve gençlerin yetiştirilmesi ve eğitiminde ebeveynlerin ve öğretmenlerin koruyucu ve rehberlik edici rolünün hesaba katılması ihtiyacını ortaya koymaktadır. Bu minvalde, dijitalleşmenin çocuk ve gençlerin psikososyal gelişiminde ve çocuk eğitimindeki rolünün özellikle ebeveynler ve öğretmenlerin

\footnotetext{
9 Yoram Eshet, "Digital Literacy: A Conceptual Framework for Survival Skills in the Digital Era” Journal of Educational Multimedia and Hypermedia, 13/1 (2004), s.93-106.

${ }^{10}$ Ellen Johanna Helsper ve Rebecca Eynon, “Digital Natives: Where is the Evidence?”. Paul A. Kirschner ve Pedro De Bruyckere, "The Myths of the Digital Native and the Multitasker" Teaching and Teacher Education, 67 (2017), s.135-142.

${ }^{11}$ Anique Scheerder, Alexander van Deursen ve Jan van Dijk, "Determinants of Internet Skills, Uses and Outcomes. A Systematic Review of the Second-and Third-Level Digital Divide", Telematics and Informatics, 34/8 (2017), s.1607-1624; Alexander Van Deursen ve Jan Van Dijk, "The First-Level Digital Divide Shifts from Inequalities in Physical Access to Inequalities in Material Access”, New Media \& Society, 21/2 (2019), s.354-375.

${ }^{12}$ Tobias Olsson, Ulli Samuelsson ve Dino Viscovi, "At risk of Exclusion? Degrees of ICT Access and Literacy among Senior Citizens”, Information, Communication \& Society, 22/1 (2019), s.55-72.

${ }^{13}$ Susan Greenfield, Mind Change: How Digital Technologies are Leaving Their Mark on Our Brains, New York: Random House Incorporated, 2015.

${ }^{14}$ Neil Selwyn, "The Digital Native-Myth and Reality", Aslib Proceedings: New Information Perspectives, 61/4 (2009), s.364-379.
} 
rol, yaklaşım ve sorumlulukları açısından değerlendirilmesi önem taşımaktadır. Çünkü yetişkinler ve dijital çağa doğmuş olan genç kuşaklar arasında gerçekten bir uçurum olmasa bile, çocuk ve gençlerin bu araçları kullanırken psikolojik iyi oluşlarının temini ve aynı zamanda öğrenme olanaklarının artırılmasını sağlayabilmek için onların kullanımlarını yönlendiren yetişkinlerin rolünün çerçevelendirilmesine ihtiyaç vardır.

\section{Amaç ve Kapsam}

Bu makalede, dijital dünyanın çocuk yetiştirme ve eğitimindeki etkileri, ebeveynler ve öğretmenler başta olmak üzere çocuk ve gençlerin eğitiminden sorumlu unsurların değişen rolleri açısından ele alınmaktadır. Amaç dijitalleşme olgusunu çocuk ve gençlerin psikososyal gelişimi zemininde dijital çağın getirisi olan öğrenme olanakları ve riskler açısından tartışmaktır. Buna göre, çocukların ve gençlerin bu çağda sahip olduğu öğrenme ve gelişim olanakları ile bu araçları kullanırken karşılaştığı riskler, bu koşullar karşısında ebeveynin değişen rolü, öğretmenin eğitimde bu dijital risk ve olanakları nasıl yöneteceği üzerinde durularak içinde bulunulan dijital çağın çocuk eğitimi ve dijitalleşme politikası açısından incelenmesi üzerinde durulmaktadır.

\section{Dijital Çağda Çocuğun Psikososyal Gelişimi ve Eğitimi Açısından Ebeveynlik}

Dünya genelinde, dijital medya araçlarına ve internete ulaşma konusunda farklılıklar bulunmakla birlikte, ${ }^{15}$ bu araçlara ulaşım her geçen gün yaygınlaşmaktadır. Türkiye İstatistik Kurumu'nun 2020 yılı Hanehalkı Bilişim Teknolojileri Kullanım Araştırması sonuçlarına göre 16-74 yaş arasında internet kullanım oranı geçen yıllara kıyasla artış göstermeye devam ederek \% 79'a ulaşmıştır. ${ }^{16}$ Hane içinde kullanılan dijital medya araçlarının sayısı; yani dijital ekran sayısı da artmakta, ${ }^{17}$ bu araçlarla tanışma yaşı ise gittikçe düşmektedir. ${ }^{18}$ Özellikle düşük sosyoekonomik düzeydeki ailelerin çocuklarının ekranlar ile tanışma yaşı ilk altı aya kadar inebilmekte, ${ }^{19}$ yine küçük yaşlarda dijital medyanın çocuk bakımında kullanılan ve çocuğu meşgul edici bir araç olarak görülmesi nedeniyle çocukların ekran önünde geçirdiği süre yaşları için önerilen miktarı çoğunlukla aşmaktadır. ${ }^{20} 13$ 16 yaşları arasındaki çocuklar dijital medya araçlarını genellikle yalnız başlarına iken kullanmaktadırlar. Bu araçları internete bağlanma, özellikle oyun, iletişim,

\footnotetext{
15 Max Roser, Hannah Ritchie ve Esteban Ortiz-Ospina, “Internet”, (2015), erişim 10 Eylül, 2020, https://ourworldindata.org/internet.

16 "Hanehalkı Bilişim Teknolojileri (BT) Kullanım Araştırması 2020", Türkiye İstatistik Kurumu, erişim 30 Kasım, 2020, https://data.tuik.gov.tr/Bulten/Index?p=Hanehalki-Bilisim-Teknolojileri-(BT)-KullanimArastirmasi-2020-33679.

17 "Digital 2020: Turkey", We are Social, erişim 30 Kasım, 2020, https://datareportal.com/reports/digital2020 -turkey.

18 "Children and Parents: Media Use and Attitudes Report 2018.", Ofcom, (2019), erişim 12 Temmuz, 2020, https://www.ofcom.org.uk/_data/assets/pdf_file/0023/190616/children-media-use-attitudes-2019report.pdf.

${ }^{19}$ John S. Hutton vd., "Shared Reading and Television across the Perinatal Period in Low-SES Households", Clinical Pediatrics, 57/8 (2018), s.904-912.

${ }^{20}$ H. K. Kabali vd., "Exposure and Use of Mobile Media Devices by Young Children", Pediatrics, 136/6 (2015), s.1044-1050.
} 
müzik dinleme ve video ya da film izleme gibi nedenlerle kullandıkları; çocukların büyük bir kısmının bu araçları hayatlarının ayrılması güç bir parçası olarak değerlendirdiği bildirilmektedir. ${ }^{21}$ Diğer yandan dünyada kendine ait dijital medya aracı edinme yaşının 3-4 civarına düşebildiği, ${ }^{22}$ erken dönemlerde çocukların kullanım alışkanlıklarının evde model aldıkları bir büyük kardeşlerinin bulunup bulunmadığından etkilendiği ${ }^{23}$ uygun yönlendirme ve olanaklar sağlandığında özellikle okul öncesi dönemdeki çocukların ekran dışı etkinliklere yönelme konusunda istekli oldukları bildirilmektedir. ${ }^{24}$ Okul çağı ile birlikte ise bu araçlar çocuğun günlük çalışmasının bir parçası olmakta, uzayan ekran süreleri okul ile ilgili öğrenme amaçlarını da kapsamaya başlamaktadır. ${ }^{25} \mathrm{Bu}$ durumun yakın dönemde en açık kanıtı, 2020 yılının başlarında Yeni Korona Virüs hastalığının (COVID19) dünya genelinde salgın olarak ilan edilmesi sonrasında her yaştan çocuk ve gençlerin eğitim amacı ile dijital medya araçları ile geçirdiği sürenin artmasıdır. ${ }^{26}$ $\mathrm{Bu}$ artış, aslında sadece eğitimsel amaçlar ile kullanımda gözlenmemiş aynı zamanda tüm aile üyelerinin, salgın sonrasında sosyal hayatta ortaya çıan yeni koşullar karşısında (evden çalışma ve zorunlu evde kalma dönemleri) iş ve eğlence amaçları ile de kullanımlarını artmıştır. ${ }^{27} \mathrm{Bu}$ dünya çapındaki güncel koşullardan da anlaşılacağı gibi, dijital teknolojiler çocukların ve gençlerin hayatlarının hızla vazgeçilmez bir parçası haline gelmektedir.

Dijital teknolojilerin çocuklar ve gençler tarafından kullanılması söz konusu olduğunda ebeveynlerin yaklaşımlarını belirleyen iki boyut bulunmaktadır. Bu iki boyut, ${ }^{28}$ ebeveynleri çocuklarının bilişsel, sosyal, duygusal gelişimlerini dikkate alarak onları dijital olanaklardan yararlandırma ve bu teknolojilerin getirdiği risklerden koruma noktasında ikilemde bırakmaktadır. Buna göre ebeveynler, çocukların bu araçları erken dönemden itibaren kullanmasının onların öğrenme olanaklarını artırdığı görüşü ile kullanımlarının artması nedeniyle çocukların bedensel sağlığg ve sosyal-duygusal gelişimleri üzerinde olumsuz etkilerden duydukları endişe arasında kalmaktadırlar. ${ }^{29}$ Bu noktada ebeveynlerin kendi dijital okuryazarlık düzeyleri, çocuklarının bu araçları kullanmasına yönelik tutumları ve yaklaşımları ile ilişkilidir. Bu araçları kullanmada daha yetkin olan ebeveynler, çocuklarının maruz kalabileceği risklerin farkında olmakla birlikte, daha az sınırlandırıcı bir yaklaşım kullanmakta, böylece öğrenme olanaklarını da artırmakta-

\footnotetext{
21 "Medya Okuryazarlığı Araştırması", (2016), Radyo Televizyon Üst Kurulu, erişim 2 Aralık, 2020, https://www.medyaokuryazarligi.gov.tr/userfiles/files/Medya\%20Okuryazarligi\%20Arastirmasi\%202015(1).p df.

22 "Children and Parents: Media Use and Attitudes Report 2018".

${ }^{23}$ Andra Siibak ve Elyna Nevski, "Older Siblings as Mediators of Infants' and Toddlers'(Digital) Media Use", The Routledge Handbook of Digital Literacies in Early Childhood, der., Ola Erstad, Rosie Flewitt, Bettina Kümmrling-Meibauer ve Iris Susana Pires Pereira, NewYork: Routledge, 2019, s.123-133.

${ }^{24}$ Stéphane Chaudron vd., Young Children (0-8) and Digital Technology: A Qualitative Exploratory Study Across Seven Countries, Ispra Italy: JRC, 2015.

25 "Medya Okuryazarlığı Araştırması".

${ }^{26}$ Sarah A. Moore vd., "Impact of the COVID-19 Virus Outbreak on Movement and Play Behaviours of Canadian Children and Youth: A National Survey", International Journal of Behavioral Nutrition and Physical Activity, 17/1 (2020), s.1-11.

${ }^{27}$ Orsolya Király vd., "Preventing Problematic Internet Use During the COVID-19 Pandemic: Consensus Guidance”, Comprehensive Psychiatry, 100 (2020), 152180. (erişim 10.09.2020).

${ }^{28}$ Livingstone vd., "Maximizing Opportunities and Minimizing Risks for Children Online".

${ }^{29}$ Livingstone vd., "Maximizing Opportunities and Minimizing Risks for Children Online".
} 
dırlar. Diğer yandan, ebeveynin ve/veya çocuğun dijital okuryazarlıklarının düşük olması beraberinde ebeveynlerin daha fazla kısıtlayıcı stratejiler kullanmasını getirmektedir. Bu durumda çocuklar ve gençler için riskler azalmakta, ancak bu tür bir yaklaşım, riskleri önlerken gelişim ve öğrenme olanaklarını da sınırlandırmaktadır. ${ }^{30}$ Aile içi ilişkilerin ve ebeveyn çocuk ilişkisinin niteliği ${ }^{31}$ ve ebeveynin genel olarak çocuk yetiştirme yaklaşımı ${ }^{32}$ da dijital teknolojilerin çocuk tarafından kullanımında rol oynamaktadır. Çocukların kullanım süresi ve alışkanlıkları, ebeveynlerin bu araçları ne sıklıkta, ne kadar süre ve hangi içerikler ile kullandıklarından etkilenmektedir. ${ }^{33}$ Bir başka deyişle, ebeveynlerin bu araçlarda geçirdikleri süre ve ilgilendikleri içerik, ayrıca içerik hakkındaki değerlendirmeleri çocuklarının dijital medya araçlarına yaklaşımının nasıl olacağını belirlemektedir.

Çocuk eğitiminde, özellikle çocuğun dijital okuryazarlığını artırmak için ebeveynlerin okuryazarlıklarının geliştirilmesi ve bu teknolojilerin eğlence ve sosyalleştirme yönlerinin ötesinde, çocukların bilgiye ulaşma ve kullanmada yetkinleşmesindeki rolünün ailelerce anlaşılması, çocukların dijital öğrenme olanaklarından daha fazla faydalanmasını mümkün kılar. Zira risklerden korumayı, çocuklarını bu araçlara ulaşımını en üst düzeyde kısıtlama zemininde tartışan ebeveynlerin öğrenme olanakları hakkında ve bu olanaklardan çocuklarını nasıl yararlandırabilecekleri konusunda desteklemelerine ihtiyaç vardır. Ebeveynler, eğitim seviyeleri artıkça, bu araçları kullanırken çocuklarına daha sık eşlik etmekte ve bu teknolojilerin öğrenilmesi ile içeriğin değerlendirilmesinde rehberlik yaklaşımını daha fazla kullanmaktadırlar. ${ }^{34}$ Ayrıca, dijital okuryazarlıkları daha yüksek olan ebeveynler, özellikle çocuklarının da bu araçlar konusunda daha bilgili olması halinde, çocuklarına daha fazla rehberlik edebilmektedirler. ${ }^{35}$

Diğer yandan, çocuklarının karşılaşabilecekleri riskleri azımsama eğiliminin de ebeveynlerce gösterilebildiği bilinmektedir. ${ }^{36}$ Hatta, bazı ebeveynler risklerin farkında olduklarını bildirseler de ebeveynlik davranışlarını bu riskleri dikkate alarak düzenleyebilmede yetersizlik yaşamaktadırlar. ${ }^{37}$ Çünkü çocuklar dijital teknolojileri kullanırken onlara ebeveynlik yapmak esnek ve duruma uygun bir iş birliği ile mümkündür. ${ }^{38}$ Riski azımsayan ebeveynlerin öğrenme olanaklarını destek-

\footnotetext{
${ }^{30}$ Livingstone vd., "Maximizing Opportunities and Minimizing Risks for Children Online".

31 Yuki Fujioka ve Erica Weintraub Austin, "The Relationship of Family Communication Patterns to Parental Mediation Styles", Communication Research, 29/6 (2002), s.642-665.

${ }^{32}$ Rita Brito vd., "Family Dynamics in Digital Homes: The Role Played by Parental Mediation in Young Children's Digital Practices Around 14 European Countries", Contemporary Family Therapy, 39/4 (2017), s.271-280.

${ }^{33}$ Alexis R. Lauricella, Ellen Wartella ve Victoria J. Rideout, "Young Children's Screen Time: The Complex Role of Parent and Child Factors", Journal of Applied Developmental Psychology, 36 (2015), s.11-17.

${ }^{34}$ Sonia Livingstone vd., "How Parents of Young Children Manage Digital Devices at Home: The Role of Income, Education and Parental Style", EUKidsOnline, London: LSE, 2015, (erişim 08.09.2018).

${ }^{35}$ Peter Nikken ve Suzanna J. Opree, "Guiding Young Children's Digital Media Use: SES-Differences in Mediation Concerns and Competence", Journal of Child and Family Studies 27/6 (2018), s.1844-1857.

${ }^{36}$ Francine Dehue, Catherine Bolman ve Trijntje Völlink, "Cyberbullying: Youngsters' Experiences and Parental Perception”, CyberPsychology \& Behavior 11/2, (2008), s.217-223.

${ }^{37}$ Loredana Covolo vd., "Children and Digital Devices: A Survey on Risk Perception and Use", European Journal of Public Health, 29/4 (2019), s.185-101.

38 Martina Smahelova vd., "Mediation of Young Children's Digital Technology Use: The Parents' Perspective", Cyberpsychology: Journal of Psychosocial Research on Cyberspace, 11/3 (2017), (erişim
} 
leyip desteklemediklerini kıyaslamak mümkün değildir. Ancak, özellikle riskler hakkında yeterince bilgi sahibi olmamak ya da riskler bilinse de kendi çocuklarının bu durumlarla karşılaşma olasılığını düşük ihtimalli bir seçenek olarak görmek ebeveynlerce ortaya konan bir yaklaşım olabilmektedir. Bu noktada ebeveynin eğitim düzeyi ve ailenin ekonomik koşulları, risklere nasıl yaklaştıklarını belirlemektedir. Düşük sosyoekonomik düzeyden ailelerin çocuklarının, ebeveyn gözetiminde olmadan bu araçları daha fazla kullanabildikleri, bir başka ifade ile, bu ailelerde çocuklara ebeveynin rehberliğinden yararlanma firsatı sunulmasının sınırlı kaldığı ve çocukların bu araçlarla zaman geçirmeye erken yaşlardan itibaren daha fazla teşvik edilebildiği gözlenmiştir. ${ }^{39}$ Yine ailenin sosyoekonomik düzeyi, özellikle ailelerin sınırlı ekonomik koşullarından hareketle, çocuklarını ekran dışı etkinliklere daha sınırlı düzeyde yönlendirmelerinde rol oynamaktadır. ${ }^{40}$ Dijital araçlarla geçirilen süre arttığında ve bu süreçte ebeveyn rehberliğinden sınırlı düzeyde yararlanma söz konusu olduğunda, düşük sosyoekonomik düzeydeki ailelerde çocukların dijital medyanın beraberinde getirdiği psikososyal ve gelişimsel risklere daha açık koşullarda yetiştikleri ifade edilebilir.

Ailenin, çocukların ve gençlerin dijital dünyaya uyumlanmasında koruyucu ve destekleyici bir rolünün olduğu görülmektedir. Bu nedenle, çocuğun dijital çağa bilişsel, sosyal ve duygusal yönlerden uyumlarını artırabilmek için, ebeveynlerin eğitsel ve destekleyici içerikler kadar, olası gelişimsel riskler hakkındaki bilgilerinin ve dijital medya okuryazarlık düzeylerinin artırılmasının önemli bir adım olduğunu söylemek mümkündür.

\section{Dijital Çağda Öğıretmenin Değişen Rolü}

Dijital çağda eğitim denildiğinde aslında ebeveynlerden önce akla okul ve eğitim öğretim faaliyetlerinin yürütücüsü olarak öğretmen gelmektedir. Eğitimde dijitalleşme olgusu, öğretimin hangi biçimlerde yapılabileceği (uzaktan, yüz yüze ya da hibrit) ve öğretimde dijital teknolojilerin öğrenme olanaklarını artırdığı görüşüne bağlı olarak teknolojiden nasıl yararlanılacağ ${ }^{4},{ }^{41}$ eğitimde modern dünyaya ve hızlı değişen ekonomik düzene nasıl uyum sağlanacağı, bilgi çağında eğitimin istihdamın planlanmasındaki rolü, dijital becerilerin yanı sıra problem çözme gibi bilişsel becerilerin gelişiminin eğitimde nasıl destekleneceği, öğrencinin merkeze alınması ve yapılandırmacı uygulamaların nasıl gerçekleştirilebileceği, öğrenenin özgürlüğü ve özerkliğinin nasıl sağlanacağı, okulların kurum olarak modernleşmesi ve çıktı kalitelerinin nasıl artırılabileceği soruları ${ }^{42}$ zemininde konuşulagelmiştir. Bir başka ifade ile, eğitim ve öğretimde dijitalleşme üst bir hedef, ulaşılmas1 gereken bir 21. Yüzyıl hedefi, öğrencilerin, öğretmenlerin ve genel olarak eğitim sisteminin kazanması gereken bir nitelik olarak ifade bulmuş, bu nedenle de

05.01.2018).

39 Orsolya Király vd.,"Preventing Problematic Internet Use During the COVID-19 Pandemic: Consensus Guidance". D.P. Cingel ve M. Krcmar, "Predicting Media Use in very Young Children: The Role of Demographics and Parent Attitudes", Communication Studies, 64/4 (2013), s.374-394.

${ }^{40}$ Nikken ve Opree, "Guiding Young Children's Digital Media Use: SES-Differences in Mediation Concerns and Competence".

${ }^{41}$ Allan Collins ve Richard Halverson, Rethinking Education in the Age of Technology: The Digital Revolution and Schooling in America, NewYork: Teachers College Press, 2018.

${ }^{42}$ Neil Selwyn, Education and Technology: Key Issues and Debates, London: Bloomsbury Publishing, 2016. 
eğitimde atılan yenileşme adımları son on yılda dijitalleşmede ilerleme adımları olarak planlanmıştır. Yani sistemler, öğrenciler arası, okullar ve bölgelerarası açılan dijital farkın incelenmesi ve kapatılmasına yönlenmişlerdir. ${ }^{43}$ Eğitimdeki bu değişim ve ilerlemelerin daha çok, dijital bilgi çağında, dünyada var olan bilimsel ve teknolojik bilgiye ulaşabilmek, o bilgiyi kullanabilmek düzleminde planlandığ 1 ve uygulamaya konulduğu gözlenmektedir. Bugün, özelikle mikro düzeyde öğrencinin dijital araçlar ile kurduğu etkileşimdeki günlük yaşamı dikkate alındığında, mevcut eğitim sisteminin öğrenmede bu teknolojilerden yararlanma hedefini öne alırken, öğrenci, öğretmen, okul ve ailelerin karşılaşabileceği dijital risklere ne derecede hazırlıklı ve planlı yaklaştı̆̆ının da değerlendirilmesi gerekmektedir. Alanyazında, öğretmenlerin, öğrencilerinin karşılaşabilecekleri risklerin farkında olduklarını gösteren betimsel çalışmalar bulunmaktadır. ${ }^{44}$ Ancak, dijital risklerin sınıf ortamında ya da okul ortamında daha bütüncül bir perspektiften incelenmesine ihtiyaç vardır. Öğretmenlerin, özellikle eğitimde dijital olanakları sınıfta kullanırken riskleri nasıl yönetebileceği konusunun henüz yeterince çalışılmadığ ifade edilebilir. ${ }^{45}$ Okul ortamında, teknoloji bağımlılığı, dijital oyun bağımlılı̆̆ı, siber zorbalık/mağduriyet, gizlilik ve kişisel verilerin güvenliği gibi olgular dikkate alındığında dijitalleşmenin öğrenci olarak çocuk ve gençler için ortaya çıkabilen olumsuz sonuçlarının da olduğu gözlemlenmektedir. Dijital dünyanın öğrenme olanaklarının yanı sıra getirdiği bu risk durumlarında nasıl davranılması gerektiği, öğretmenlerin sorumluluklarının neler olduğu, çocukların gelişim ve öğrenme olanaklarının en üst seviye çıkarılması, karşılaşabilecekleri risklerin en aza indirilmesi konusunda okulların nasıl bir plan doğrultusunda ilerlemesi gerektiği soruları bu konuda bir politika geliştirilmesini şart koşmaktadır. ${ }^{46}$ Çünkü dijital çağın ebeveynler için getirdiği ikilem (olanaklardan yararlandırırken, risklerden koruyabilme), sadece onlarla sınırlı değildir. Bu ikilem öğretmenler ve diğer eğitim unsurları için de geçerlidir. ${ }^{47}$

Hem ebeveynlerin hem de öğretmenlerin bu durum ile baş ederken sahip oldukları ilk kaynağın onların dijital teknolojiler ile ilgili yeterlikleri ve dijital okuryazarlık düzeyleri olduğu ifade edilebilir. Bu teknolojileri bilme, amaca uygun kullanma, uygun içerikler üreterek dijital dünyaya katılma ve bunun için gereken bilişsel ve sosyal stratejileri işe koşabilme yeterlikleri; bir başka ifade ile dijital okuryazarlık açısından yeterli düzeyde olan ebeveyn ya da öğretmenlerin olası öğrenme olanaklarını ve riskleri öngörebilme düzeyleri de artmaktadır. ${ }^{48}$ Öğret-

\footnotetext{
${ }^{43}$ Fredrico Cruz-Jesus vd., "The Education-Related Digital Divide: An Analysis for the EU-28”, Computers in Human Behavior, 56 (2016), s.72-82.

${ }^{44}$ Fatih Yaman vd., "Okul Rehber Öğretmenleri Gözünden İlköğretim Öğrencilerinin Karşılaştıkları Çevrimiçi Riskler”, Turkish Online Journal of Qualitative Inquiry (TOJQI), 8/4 (2017), s.415-427; Eray Yılmaz, Levent Yusuf Şahin ve Davut Kodaş, "Öğretmenlerin Dijital Veri Güvenliği Farkındalığı”, Sakarya University Journal of Education, 6/2 (2016), s.26-45.

${ }^{45}$ Lana Ciboci ve Danijel Labaš, "Digital Media Literacy, School and Contemporary Parenting”, Medijske Studije, 10/19 (2019), s.83-101; Tracey Burns ve Gottschalk Francesca, der., Educating 21st Century Children: Emotional Well-being in the Digital Age, Educational Research and Innovation, Paris: OECD, 2019.

${ }^{46}$ Sonia Livingstone, "Erasmus Medal Lecture 2018 AE GM Barcelona: Realizing Children's Rights in Relation to the Digital Environment “, European Review, 28 (2020), s.1-14. (erişim 17.09.2020).

${ }^{47}$ Burns ve Francesca, Educating 21st Century Children.

${ }^{48}$ Monica Johannesen, Leikny Øgrim ve Tonje Hilde Giæver, "Notion in Motion: Teachers' Digital Competence", Nordic Journal of Digital Literacy, 9/4 (2014), s.300-312.
} 
menlerin, mesleklerini icra ederken dijital teknolojilerin sunduğu olanaklardan faydalanması konusunda desteklenmesini hedefleyen yaklaşımların onların sadece öğrenme olanaklarını artırma hedefine hizmet etmek ile sınırlı kaldığında yeterince verim elde edilemeyeceğini öngörmek mümkündür.

Özetle, çocukların ve gençlerin gelişimi ve yetişmesinde rolü olan tüm yetişkinlerin ve kurumların, eğitimde dijitalleşme hedefine yönelirken, olanakları ve riskleri yönetebilmek amacıyla dijital okuryazarlık yeterliği kazanmasını hedefleyen işbirliğine dayalı, ${ }^{49}$ bütüncül dijital eğitim politikalarına ihtiyaç duyulmaktadır. ${ }^{50}$ Örneğin, I. Türkiye Çocuk ve Medya Stratejisi ve Uygulama Planı 2014-2018 Strateji Belgesi, ${ }^{51}$ çocukları medyanın olumsuz etkilerinden korumak ve çocuklar için olumlu etkilerini artırmak amacıyla, toplumda medya okuryazarlığının artırılması için bir eylem planı önermiştir. Bu strateji ve eylem planının, dijital medya odağa alınarak her geçen gün değişen ve çeşitlenen dijital olanak ve risklerin yönetilmesi amacını kapsayan bir anlayış için izlenebilecek bir çerçeve sunduğu ifade edilebilir.

\section{Tartışma, Sonuç ve Öneriler}

Birleşmiş Buraya kadar dijitalleşen dünya gerçeğinin çocuğun günlük hayatına etkisi bulunan ve onun yetişmesinden, gelişiminden ve eğitiminden sorumlu olan ebeveyenler ve öğretmenlerin dijital dünyada hangi koşullar ile karşı karşıya olduğunun açıklanmasına çalışıldı. Dünyanın içinden geçtiği dijital dönüşüm paydaşlar nezdinde çeşitli çözüm girişimlerini beraberinde getirmektedir. Bu manada, burada, çocukların ve gençlerin dijital dünyada karşılaşabilecekleri risklerin en aza indirgenmesi ve onların öğrenme olanaklarına ulaşmalarının desteklenmesi için atılabilecek çeşitli adımlardan söz edilmektedir.

$\mathrm{Bu}$ adımlardan ilki, eğitimde dijital olanaklara ulaşma ve dijital medya araçlarını kullanabilme yeterliğinin kazanılmasında çocuklar arasında fırsat eşitliğinin sağlanmasıdır. Bu eşitlik sadece dijital medya araçlarına ya da internete ulaşmanın herkes için yaygınlaştırılmasını kapsamamaktadır. Nitekim bu teknik desteğin sağlanması için eğitim sistemimizde son on yılda FATİH (Fırsatları Artırma Teknolojiyi İyileştirme Hareketi) Projesi uygulamaya konulmuş; ancak bu çalışmanın öğrenciler arasındaki dijital farkı kapatmadaki olası katkısı henüz yeterince açık ortaya konulmamıştır. ${ }^{52}$ Bu kapsamda sınıf içinde akıllı tahtaların kullanımı yaygınlaştırılmış, müfredatın dijital olanaklardan yararlanarak desteklenmesi ile ilgili çabalar, öğretmenlerin ve öğrencilerin ihtiyaçlarını yeterince karşılayamamış görünmektedir. ${ }^{53}$ Dijital çağın öğrenme olanaklarından çocukların fırsat eşitliği ilke-

49 Disney Leigh, Emma Connelly ve Bethany Waterhouse, "Digital Literacy-Teacher and Parent Conversations", Practical Literacy: The Early and Primary Years, 22/3 (2017), s.13.

${ }^{50}$ Livingstone, "Realizing Children's Rights in Relation to the Digital Environment".

51 “I. Türkiye Çocuk ve Medya Stratejisi ve Uygulama Planı 2014-2018 Strateji Belgesi Birinci Taslağı”, I. Türkiye Çocuk ve Medya Kongresi, İstanbul, 14-15 Kasım 2013, erişim 28 Kasım, 2020, http://cocukvakfi.org.tr/wp-content/dosya/11k.pdf.

${ }^{52}$ Kıvanç Bozkuş ve Mehmet Fatih Karacabey, "FATİH Projesi ile Eğitimde Bilişim Teknolojilerinin Kullanımı: Ne Kadar Yol Alındı?”, Yaşadıkça Eğitim, 33/1 (2019), s.17-32; Veysel Demirer ve Cemal Hakan Dikmen, "Öğretmenlerin FATİH Projesine Yönelik Görüşlerinin Teknolojik Pedagojik Alan Bilgisi Bağlamında İncelenmesi”, İlköğretim Online, 17/1 (2018), s.26-46. (erişim 16.06.2020).

${ }^{53}$ Hüseyin Melih Altın ve Filiz Kalelioğlu, "Fatih Projesi ile İlgili Öğrenci ve Öğretmen Görüşleri”, Başkent 
sine dayalı olarak yararlanabilmesi için teknik boyutta atılan adımların güncel ihtiyaçlara göre takibi ve iyileştirilmesi gerekmektedir. Bununla birlikte, acil durumlarının ötesinde, önleyici bir bakışla dijital olanaklardan yararlanmanın herkes için yaygınlaştırılmasına yönelik planlamalar yoluna gidilmesi gerekmektedir. Dijitalleşmenin dünyanın her yerinde aynı hızda ve yaygınlıkta gerçekleştiğini söylemek mümkün değildir. Kaynaklara erişim konusunda yaşanan eşitsizlikler, 'dijital bölünme' ile açıklanmaktadır. Bu yönüyle de dijitalleşme gruplar ve kişiler arasında Matthew etkisinin ${ }^{54}$ izlenmesine; yani ileride olanın daha da ilerlemesini sağlarken geride ve olanaklardan yoksun kalanın bu olanaklara ulaşımını daha da zorlaştırmaktadır. İşte bu noktada, özellikle sosyoekonomik ve/veya özel gereksinimleri açısından dezavantajlı konumdaki çocukların eğitimi ve ailelerinin bu eğitimi destekleyebilme yetkinliği dikkate alındığında, dijital olanaklara ulaşımın kişisel çabalar ile kapatılabilecek olanın ötesinde olduğunu ifade etmek gerekir. Özellikle eğitim alanında siyasi erkin bu farkın daha da açılmaması ve mevcut farkın kısa sürede kapatılması ile ilgili çabalarının başat rol oynayacağı değerlendirilmektedir.

İkinci olarak politika yapıcıların görevi teknolojik araçlara ulaşmayı yaygınlaştırmanın ötesinde, dijitalleşme karşısında çocukların, ailelerin ve başta öğretmen olmak üzere tüm eğitim unsurlarının desteklenmesidir. ${ }^{55}$ Öncelikle, çocukların bulundukları gelişim dönemleri gözetilerek uygun içerikler ile tanıştırılması, çocuklarına rehberlik edebilmek için anne babaların dijital çağda ebeveynlik becerilerinin geliştirilmesine yönelik çalışmalar yapılması, çocukların, ailelerin ve öğretmenlerin dijital medya okuryazarlıklarının artırılmasına yönelik çalışmalar yapılması önem kazanmaktadır. ${ }^{56}$ Zira bu anlamda, 2007 yılında ilköğretim okulları 6-8. sınıflarında, çağın ihtiyacına yönelik olarak medya okuryazarlığı dersi konulmuştur ${ }^{57}$. Bu dersin öğrencilerin çoğunluğu tarafından yararlı olarak değerlendirildiği, ancak sınıf içinde yapılan etkinliklerin daha yeterli, hale getirilmesine duyulan ihtiyaç rapor edilmiştir..$^{58}$ Diğer yandan öğretmen adaylarının medya okuryazarlıklarının artırılmasına yönelik dersler öğretmen yetiştirme programlarında yer almakla birlikte, öğretmen adaylarını bu konuda daha fazla bilgilenmeye ihtiyaç duyduğu görülmektedir. ${ }^{59} \mathrm{Hem}$ olanaklardan yararlanmak hem de risklerden kaçınabilmek açılarından ebeveyn ve öğretmenlerin çocuklara ve gençlere rehberlik yapabilmeleri için desteklenmeye açık gereksinimleri bulunmaktadır. Öğrencilerin dijital yeterlik ve okuryazarlıklarının artışında, aile ve okul sistemlerinin bu yeterliklerin kazandırılması için ortak hareket etmesi de önemli bir eşiktir. ${ }^{60}$ Ayrıca, öğretmenler derslerinde dijital içerik ve materyallerden yararlanma

\footnotetext{
University Journal of Education, $2 / 1$ (2015), s.89-105.

${ }^{54}$ Robert K. Merton, "The Matthew Effect in Science: The Reward and Communication Systems of Science are Considered", Science, 159/3810 (1968), s.56-63.

${ }^{55}$ Livingstone, "Realizing Children's Rights in Relation to the Digital Environment".

56 "I. Türkiye Çocuk ve Medya Stratejisi ve Uygulama Planı 2014-2018 Strateji Belgesi Birinci Taslağı".

${ }^{57}$ İrfan Erdoğan, Milli Eğitime Dair, Ankara: Nobel, 2014, s.77.

58 "Medya Okuryazarlığı Araştırması".

${ }^{59}$ Rıdvan Ata ve Kasım Yıldırım, "Öğretmen Adaylarının Medya Okuryazarlı̆ğ Dersi Kapsamında İnternet ve Sosyal Medya Kullanımları”, Journal of Kirsehir Education Faculty, 17/ 2 (2016), s.581-602; Sevilay Aydemir ve Özden Demirkan, "Gender-Aware Media Literacy Training: A Needs Analysis Study for Prospective Teachers", Educational Policy Analysis and Strategic Research, 13/1 (2018), s.6-30.

${ }^{60}$ Kristiina Kumpulainen ve Julia Gillen, "Young Children's Digital Literacy Practices in the Home: A
} 
konusunda teşvik edilmelerinin ötesinde, bu konuda kendilerini geliştirmelerine yönelik desteklerden yararlandırılmalıdır. Çünkü bu yönde sunulan destekler öğretmenlerin dijital okuryazarlık konusundaki güvenlerini artırdığı ölçüde, öğretimde dijital olanaklardan yararlanma konusundaki tutumlarını olumlu yönde etkilemektedir. ${ }^{61} \mathrm{Bu}$ nedenle, öğretmenlerin dijital medya okuryazarlıklarının desteklenmesinin bir mesleki gelişim hedefi olarak ele alınması ve bu konuda düzenli bir danışmanlıktan yararlanmalarının sağlanması önerilebilir. Gün geçtikçe yeni uygulamalar, içerikler sunulmaktadır. Buna göre, öğretmenlerin ve ailelerin dijital araç, uygulama ve içeriklerin eğitimsel amaçla kullanımı konusunda alabilecekleri düzenli danışma hizmetleri seçeneklerinin geliştirilmesine ihtiyaç bulunmaktadır. Ayrıca, öğretmenlerin bu teknolojilerin kullanımı sahip olmaları gereken dijital okuryazarlığın iki yönlü sunularak, öğrenme olanaklarının artırılması kadar olası risklerden kendilerini ve öğrencilerini koruyabilme, risklerden korunma konusunda öğrencilerine rehberlik yapabilme yeterliklerinin de desteklenmesi hedeflenmelidir. Benzer biçimde, özellikle okullarda karşılaşılabilecek dijital riskler konusunda okul psikolojik danışmanları ve psikologları ile işbirliği ve sağlanmasının yararlı olacağı ileri sürülebilir.

Çocuk ve gençlerin gelişim ve öğrenmesinde rol alan yetişkinlerin dijital beceriler ve okuryazarlık açısından eğitimin merkezi otoritesince desteklenmesi; ${ }^{62}$ yani sadece çocukların değil aileler ve öğretmenlerin, okulların sürekli güncellenen bir dijital okuryazarlık becerisi kazanmasına yönelik çalışmaların yapılması yaygın bir eğitim politikası haline getirilmelidir.

Diğer yandan dijital teknolojiler, sadece öğrenme olanaklarını artırmamakta, aynı zamanda her geçen gün çocuk gelişimi açısından yeni riskleri de beraberinde getirebilmektedir. Bu riskler hakkında bilgi sahibi olmak, çocukların korunması ve bilgilenmesinde yardımcı olabilmek açısından öncelikle ailelerin ve öğretmenlerin bilgi sahibi olması gerekmektedir. Bu ailelerin ya da öğretmenlerin ya da okul yönetimlerinin bireysel çabaları ile baş edebilecekleri bir durum olmaktan ziyade, eğitim planlamasında okul aile işbirliğini sağlayan ve çocuğun bağlantıda olduğu sosyal sistemlerinin rolünü de hesaba katan bütüncül bir politikayı gerektirmektedir. Nitekim, son on yıldır Türkiye'den de toplanan verileri kapsayan Avrupa'da çocukların internet kullanımına yönelik Avrupa Çevirimiçi Çocuklar (EUKidsOnline $)^{63}$ projesi gibi uluslararası ve RTÜK, Çocuk Vakfı gibi ulusal kurum ve kuruluşlarca yürütülen çalışmalar, farklı yaş gruplarından çocukların siber zorbalık, kişisel verilerin korunmasının ihlali, ebeveynin çocuğun gizlilik hakkını ihlali, bilgisayar ve çevirim içi oyunlara yönelik bağımlılık gibi çok yönlü risklerin takibini yapmaktadır. Bu çalışmaların bulguları pek çok ülkenin dijital çağda çocuk, aile ve okula yönelik politika kararlarını etkilemektedir. Tıpkı dijital medyanın sunduğu öğrenme olanakları için olduğu gibi, olası risklerin değerlendirilmesi, bu riskler hakkında çocukların olduğu kadar aileler ve okulların da bilgi sahibi olması ve korunmasının teminat altına alınması acil bir gereksinimdir. Zira, bütüncül

Review of the Literature", Cost Action ISI1410 DigiLitEY, 20/3 (2017), 472-499. (erişim 15.08.2020)

${ }^{61}$ Courtney K. Blackwell, Alexis R. Lauricella ve Ellen Wartella, "Factors Influencing Digital Technology Use in Early Childhood Education”, Computers \& Education, 77 (2014), s.82-90.

62 "I. Türkiye Çocuk ve Medya Stratejisi ve Uygulama Planı 2014-2018 Strateji BelgesiBirinci Taslağı".

63 "EU Kids Online Türkiye”, erişim 10 Kasım, 2018, http://eukidsonline.metu.edu.tr/. 
olarak aile ve okul sistemleri yerine sadece çocukların korunmasını amaçland1ğında, örtük biçimde ailelerin ve okulların riskler hakkında yeterince bilgi ve bu riskleri bertaraf etme becerisine sahip olduğu varsayılmış olur. Halbuki bu kadar hızlı bir dönüşüm ve değişimi beraberinde getiren bilgi çağında, olası risklerin ve olanakların sadece ailelerin ve okulların çabaları ile yönetilmesi mümkün değildir. Burada, çocuğun gelişimsel özellikleri ve bireysel ihtiyaçlarını gözeten ve çocuğa rehberlik edebilmede aileleri ve okulu destekleyen ulusal bir dijital okuryazarlık anlayışına ve bu yeterliğin toplum genelinde kazandırılmasına ihtiyaç vardir.

Dijital çağ beraberinde günlük yaşamda köklü değişimler getirmiştir. Bu değişimlerin yakından izlenebildiği eğitim alanı, önemli bir tartışma konusu olmayı halen sürdürmektedir. Burada, dijitalleşme olgusu çocuk ve gençlerin psikososyal gelişimi ve eğitimi açısından ailenin ve öğretmen başta olmak üzere eğitim sisteminin değişen rolleri ve ihtiyaçları düzleminde tartışılmıştır. Çocuk yetiştirme ve eğitimde dijitalleşme denildiğinde çoğunlukla, teknolojik araçlara ve internete erişimin artırılması ve bu sayede dijital olarak oluşturulan ve saklanan evrensel bilgiye ulaşmak için gerekli donanıma sahip olma ve bu donanımı kullanma ifade edilmektedir. Ancak bunu mümkün kılan dijital okuryazarlık becerisi ve bu becerinin genç nesillerce edinilmesi temelde ailenin ve okulun sorumlulukları olarak görülmektedir. Çocuklar ve gençlerin evrensel bilgiye ulaşırken dijital dünyanın risklerinden korunmasının en üst seviyede sağlanması, dijital olanaklardan yararlandırılmasının da teşvik edilmesi temel paradigma olmalıdır. Diğer yandan ailenin ve okulun koruyucu ve destekleyici rolü, eğitimde dijitalleşme politikasından ve yönetim erkinin desteğinden bağımsız yürütülemez. Bu noktada, dijitalleşme olgusu toplumun tüm bireyleri için bir hayat boyu öğrenme ve eğitim; aynı zamanda öğretmenler için bir mesleki gelişim ve eğitim konusu haline getirilmelidir. Bu nedenle, çocuklar ya da gençler için sunulacak olan bir dizi dijital beceri programından önce ve acil olarak, çocukların gelişim ve öğrenme ihtiyaçlarını karşılamak için anne, baba ve öğretmenlerin ihtiyaç duyacakları dijital yeterlilikleri artıracak iyi planlanmış destek programları uygulanmalıdır. Bu sayede kuşaklar arası olası dijital boşlukların aşılması için köprüler kurmak mümkün olabileceği gibi, hali hazırda dijital okuryazarlık becerisi ve yetkinlikleri gelişmiş olan yetişkinlerin çocuklara ve gençlere bu yeterliklerini aktarmada desteklenmeleri mümkün olabilir.

\section{Kaynakça}

Altın, Hüseyin Melih ve Filiz Kalelioğlu. "Fatih Projesi ile İlgili Öğrenci ve Öğretmen Görüşleri”. Başkent University Journal of Education. 2/1(2015): 89105.

Ata, Rıdvan ve Kasım Yıldırım. "Öğretmen Adaylarının Medya Okuryazarlığı Dersi Kapsamında İnternet ve Sosyal Medya Kullanımları”. Journal of Kirsehir Education Faculty. 17/2 (2016): 581-602.

Aydemir, Sevilay ve Özden Demirkan. "Gender-Aware Media Literacy Training: A Needs Analysis Study for Prospective Teachers". Educational Policy Analysis and Strategic Research. 13/1 (2018): 6-30. 
Blackwell, Courtney K., Alexis R. Lauricella ve Ellen Wartella. "Factors Influencing Digital Technology Use in Early Childhood Education". Computers \& Education. 77 (2014): 82-90.

Bozkuş, Kıvanç ve Mehmet Fatih Karacabey. "FATİH Projesi ile Eğitimde Bilişim Teknolojilerinin Kullanımı: Ne Kadar Yol Alındı?”. Yaşadıkça Eğitim. 33/1 (2019): 17-32.

Brito, Rita, Rita Francisco, Patrícia Dias ve Stephane Chaudron. "Family Dynamics in Digital Homes: The Role Played by Parental Mediation in Young Children's Digital Practices around 14 European Countries". Contemporary Family Therapy. 39/4 (2017): 271-280.

Buckingham, David. "Defining Digital Literacy-What Do Young People Need to Know About Digital Media?”. Nordic Journal of Digital Literacy. 4/10 (2015): 21-34.

Burns, Tracey ve Gottschalk Francesca. Der., Educating 21st Century Children: Emotional Well-being in the Digital Age. Educational Research and Innovation. Paris: OECD, 2019.

Chaudron, Stéphane, M. E. Beutel, Veronica Donoso Navarrete, M. Dreier, Ben Fletcher-Watson, A. S. Heikkilä, V. Kontríková vd. Young Children (0-8) and Digital Technology: A Qualitative Exploratory Study Across Seven Countries. ISPRA, Italy: JRC, 2015. https://publications.jrc.ec.europa.eu/repository/ handle/JRC93239. (erişim 12.07.2020).

Ciboci, Lana ve Danijel Labaš. "Digital Media Literacy, School and Contemporary Parenting". Medijske Studije. 10/19 (2019): 83-101.

Cingel, D. P. ve M. Krcmar. "Predicting Media Use in very Young Children: The Role of Demographics and Parent Attitudes". Communication Studies. 64/4 (2013): 374-394.

Collins, Allan ve Richard Halverson. Rethinking Education in the Age of Technology: The Digital Revolution and Schooling in America. NewYork: Teachers College Press, 2018.

Covolo, Loredana, J. Roncali, D. Zaniboni, V. Mapelli, E. Ceretti ve U. Gelatti. "Children and Digital Devices: A Survey On Risk Perception and Use". European Journal of Public Health. 29/4 (2019): 185-101.

Cruz-Jesus, Frederico, María Rosalía Vicente, Fernando Bacao ve Tiago Oliveira. "The Education-Related Digital Divide: An Analysis for the EU-28". Computers in Human Behavior. 56 (2016): 72-82.

Dehue, Francine, Catherine Bolman ve Trijntje Völlink. "Cyberbullying: Youngsters' Experiences and Parental Perception”. CyberPsychology \& Behavior. 11/ 2 (2008): 217-223.

Demirer, Veysel ve Cemal Hakan Dikmen. "Öğretmenlerin FATİH Projesine Yönelik Görüşlerinin Teknolojik Pedagojik Alan Bilgisi Bağlamında İncelenmesi”. İlköğretim Online. 17/1 (2018): 26-46. https://core.ac.uk/download/pdf/230034853.pdf (erişim 16.06.2020).

Erdoğan, İrfan. Milli Eğitime Dair. Ankara: Nobel, 2014. 
Eshet, Yoram. "Digital Literacy: A Conceptual Framework for Survival Skills in the Digital Era". Journal of Educational Multimedia and Hypermedia. 13/1 (2004): 93-106.

Fujioka, Yuki ve Erica Weintraub Austin. "The Relationship of Family Communication Patterns to Parental Mediation Styles". Communication Research. 29/6 (2002): 642-665.

Greenfield, Susan. Mind Change: How Digital Technologies are Leaving Their Mark on Our Brains. NewYork: Random House Incorporated, 2015.

Helsper, Ellen Johanna ve Rebecca Eynon. "Digital Natives: Where is the Evidence?”. British Educational Research Journal. 36/3 (2010): 503-520.

Hutton, John S., Li Lin, Rachel Gruber, Jennifer Berndsen, Thomas DeWitt, Judith B. Van Ginkel ve Robert T. Ammerman. "Shared Reading and Television Across the Perinatal Period in Low-SES Households". Clinical Pediatrics. 57/8 (2018): 904-912.

Johannesen, Monica, Leikny Øgrim ve Tonje Hilde Giæver. "Notion in Motion: Teachers' Digital Competence". Nordic Journal of Digital Literacy. 9/04 (2014): 300-312.

Kabali, H. K., Irigoyen, M.M., Nunez-Davis, R., Budacki, J.G., Mohanty, S.H., Leister, K.P. ve Bonner, R.L. "Exposure and Use of Mobile Media Devices by Young Children”. Pediatrics. 136/ 6 (2015): 1044-1050.

Kirschner, Paul A. ve Pedro De Bruyckere. "The Myths of the Digital Native and the Multitasker". Teaching and Teacher Education. 67 (2017): 135-142.

Király, Orsolya, Marc N. Potenza, Dan J. Stein, Daniel L. King, David C. Hodgins, John B. Saunders, Mark D. Griffiths vd. "Preventing Problematic Internet Use During the COVID-19 Pandemic: Consensus Guidance". Comprehensive Psychiatry, 100 (2020): 152180. https://doi.org/10.1016/j.comppsych.2020. 152180. (erişim 10.09.2020).

Kumpulainen, Kristiina ve Julia Gillen. "Young Children's Digital Literacy Practices in the Home: A Review of the Literature". Cost Action ISI1410 DigiLitEY. 20/3 (2017): 472-499. http://digilitey.eu/wpcontent/uploads/2018/02/WG-1-Lit-Review-04-12-17.pdf (erişim 15.08.2020).

Lauricella, Alexis R., Ellen Wartella ve Victoria J. Rideout. "Young Children's Screen Time: The Complex Role of Parent and Child Factors". Journal of Applied Developmental Psychology. 36 (2015): 11-17.

Leigh, Disney, Emma Connelly ve Bethany Waterhouse. "Digital LiteracyTeacher and Parent Conversations". Practical Literacy: The Early and Primary Years. 22/3 (2017): 13-15.

Livingstone, Sonia. "Erasmus Medal Lecture 2018 AE GM Barcelona: Realizing Children's Rights in Relation to the Digital Environment”. European Review. 28 (2020): 1-14. http://eprints.lse.ac.uk/103563/ (erişim 17.09.2020). 
Livingstone, Sonia, Kjartan Ólafsson, Ellen J. Helsper, Francisco LupiáñezVillanueva, Giuseppe A. Veltri ve Frans Folkvord "Maximizing Opportunities and Minimizing Risks for Children Online: The Role of Digital Skills in Emerging Strategies of Parental Mediation”. Journal of Communication. 67/1 (2017): 82-105.

Livingstone, Sonia, Mascheroni, G., Dreier, M., Chaudron, S. ve Lagae, K. “How Parents of Young Children Manage Digital Devices at Home: The Role of Income, Education and Parental Style". EUKidsOnline. London: LSE, 2015. https://eprints.lse.ac.uk/63378/1/_lse.ac.uk_storage_LIBRARY_Secondary_1 ibfile_shared_repository_Content_EU\%20Kids\%20Online_EU_Kids_Online _How\%20parents\%20manage\%20digital\%20devices_2016.pdf. (erişim 08.09.2018).

Madeleine J. George, Michael A. Russell, Joy R. Piontak ve Candice L. Odgers. "Concurrent and Subsequent Associations Between Daily Digital Technology Use and High-Risk Adolescents' Mental Health Symptoms”. Child Development. 89/1 (2018): 78-88.

Merton, Robert K. "The Matthew Effect in Science: The Reward and Communication Systems of Science are Considered". Science. 159/3810 (1968): 56-63.

Moore, Sarah A., Guy Faulkner, Ryan E. Rhodes, Mariana Brussoni, Tala ChulakBozzer, Leah J. Ferguson, Raktim Mitra vd. "Impact of the COVID-19 Virus Outbreak on Movement and Play Behaviours of Canadian Children and Youth: A National Survey". International Journal of Behavioral Nutrition and Physical Activity. 17/1 (2020): 1-11.

Nikken, Peter ve Suzanna J. Opree. “Guiding Young Children's Digital Media Use: SES-Differences in Mediation Concerns and Competence". Journal of Child and Family Studies. 27/6 (2018): 1844-1857.

Ofcom. "Children and Parents: Media Use and Attitudes Report 2018”. Erişim 12 Temmuz, 2020 . https://www.ofcom.org.uk/_data/assets/pdf_file/0023/190616/childrenmedia-use-attitudes-2019-report.pdf.

Olsson, Tobias, Ulli Samuelsson ve Dino Viscovi. “At Risk of Exclusion? Degrees of ICT Access and Literacy Among Senior Citizens". Information, Communication \& Society. 22/1 (2019): 55-72.

Prensky, Marc. "Digital Natives, Digital Immigrants". On the Horizon. 9/5 (2001):1-6. https://www.marcprensky.com/writing/Prensky\%20-\%20Digital\%20 Natives,\%20Digital\%20Immigrants\%20-\%20Part1.pdf. (erişim 15.08.2020).

Roser, Max, Hannah Ritchie ve Esteban Ortiz-Ospina. "Internet”. (2015). Erişim 10 Eylül, 2020. https://ourworldindata.org/internet.

Radyo Televizyon Üst Kurulu. "Medya Okuryazarlığı Araştırması". (2016). Erişim 2 Aralık, 2020. https://www.medyaokuryazarligi.gov.tr/userfiles/files/ Medya\%20Okuryazarligi\%20Arastirmasi\%202015(1).pdf. 
Scheerder, Anique, Alexander van Deursen ve Jan van Dijk. "Determinants of Internet Skills, Uses and Outcomes. A Systematic Review of the Second-and Third-Level Digital Divide". Telematics and Informatics. 34/8 (2017): 16071624.

Selwyn, Neil. Education and Technology: Key Issues and Debates. London: Bloomsbury Publishing. 2016.

Selwyn, Neil. "The Digital Native-Myth and Reality". Aslib Proceedings: New Information Perspectives. 61/4 (2009): 364-379.

Siibak, Andra ve Elyna Nevski. "Older Siblings as Mediators of Infants' and Toddlers'(Digital) Media Use". The Routledge Handbook of Digital Literacies in Early Childhood. Der., Ola Erstad, Rosie Flewitt, Bettina KümmrlingMeibauer ve Iris Susana Pires Pereira, NewYork: Routledge. 2019: 123-133.

Sjöberg, Mats, Hung-Han Chen, Patrik Floréen, Markus Koskela, Kai Kuikkaniemi, Tuukka Lehtiniemi ve Jaakko Peltonen. "Digital Me: Controlling and Making Sense of My Digital Footprint". International Workshop on Symbiotic Interaction. Der., Luciano Gamberini vd., Cham: Springer. 2016: 155-167.

Smahelova, Martina, Dana Juhová, Ivo Cermak ve David Smahel. "Mediation of Young Children's Digital Technology Use: The Parents' Perspective". Cyberpsychology: Journal of Psychosocial Research on Cyberspace. 11/3 (2017). https://cyberpsychology.eu/article/view/8561/7732 (erişim 05.01.2018).

Tsui, Lokman. "The Panopticon as the Antithesis of a Space of Freedom: Control and Regulation of the Internet in China". China Information. 17/2 (2003): 6582.

Türkiye İstatistik Kurumu. "Hanehalkı Bilişim Teknolojileri (BT) Kullanım Araştırması 2020”. Erişim 30 Kasım, 2020. https://data.tuik.gov.tr/ Bulten/Index?p=Hanehalki-Bilisim-Teknolojileri-(BT)-Kullanim-Arastirma si-2020-33679.

Van Deursen, Alexander ve Jan Van Dijk. “The First-Level Digital Divide Shifts from Inequalities in Physical Access to Inequalities in Material Access". New Media \& Society. 21/2 (2019): 354-375.

Van Dijk, Jan. "Digital Divide Research, Achievements and Shortcomings". Poetics. 34 (2006): 221-235.

We are Social. "Digital 2020: Turkey". Erişim 30 Kasım, 2020. https://datareportal.com/reports/digital-2020-turkey.

Wentz, Reinhard. "Visibility of Research: FUTON Bias". The Lancet. 360/9341 (2002): 1256.

Yaman, Fatih, Onur Dönmez, Zeynep Çoban ve Hatice Ferhan Odabaşı. "Okul Rehber Öğretmenleri Gözünden İlköğretim Öğrencilerinin Karşılaştıkları Çevrimiçi Riskler”. Turkish Online Journal of Qualitative Inquiry (TOJQI). 8/4 (2017): 415-427.

Yılmaz, Eray, Levent Yusuf Şahin ve Davut Kodaş. “Öğretmenlerin Dijital Veri Güvenliği Farkındalığı”. Sakarya University Journal of Education. 6/2 (2016): 26-45. 
Zuboff, S. "Big Other: Surveillance Capitalism and the Prospects of an Information Civilization". Journal of Information Technology. 30/1 (2015): 75-89.

I. Türkiye Çocuk ve Medya Kongresi İstanbul, 14-15 Kasım 2013. "I. Türkiye Çocuk ve Medya Stratejisi ve Uygulama Planı 2014-2018 Strateji Belgesi Birinci Taslağı". Erişim, 28 Kasım, 2020. http://cocukvakfi.org.tr/wpcontent/dosya/11k.pdf. 


\title{
Parenting and Education in Digital Era: Changing Roles
}

\author{
GAMZE İNAN KAYA
}

Abstract: Digitalization, deeply affecting daily life in almost every aspect, has brought changes to roles and duties of parents and teachers in relation to psychosocial development and education of children and youth. These duties and responsibilities rely on an idea, which emphasizes maximizing digital learning opportunities while minimizing potential digital risks for children and youth. That is because of the current context of the world, in which digitalization has been an indispensable part of daily lives of all. Stating central role of digital literacy, we have inspected the notion of digitalization in relation to its effect on young people's psychosocial development and education by emphasizing the changing roles of parents' and teachers'. An urgent need for a comprehensive digital literacy policy that is supporting parents and teachers has been proposed.

Keywords: Digitalization, Parenting education, Digital opportunities, Digital risks 